\title{
Colon Leiomyoma
}

National Cancer Institute

\section{Source}

National Cancer Institute. Colon Leiomyoma. NCI Thesaurus. Code C5492.

A well-circumscribed benign smooth muscle neoplasm arising from the colon. It is characterized by the presence of spindle cells with cig ar-shaped nuclei, interlacing fascicles, and a whorled pattern. 